\title{
The evolution of corporate governance in Italy: formal convergence or path-dependence?
}

\author{
Alessandro Zattoni*
}

Ricevuto il 19.11.2019-Accettato il 29.11.2019

\begin{abstract}
In this study, we explore the recent evolution of the Italian governance model, in order to better understand the triggers and the consequences for all stakeholders. In more details, we start highlighting the evolution of the national regulatory environment, in term of both corporate law and good governance code. Then we focus on three key elements of the corporate governance of Italian listed companies, i.e., the ownership structure, the board of directors, and the executive compensation. For each element, we present their traditional and current characteristics.
\end{abstract}

Keywords: corporate governance, Italy, corporate law, good governance code.

Sommario. L'evoluzione della corporate governance in Italia: formale convergenza o path-dependence? In questo studio si esplora la recente evoluzione del modello di governance italiano, al fine di comprenderne i fattori scatenanti e le conseguenze per tutti gli stakeholders. Più in dettaglio, s'inizia evidenziando l'evoluzione del contesto normativo nazionale, sia in termini di diritto societario, sia di Codice di Autodisciplina. Ci si focalizza poi su tre fattori chiave del governo societario delle imprese italiane quotate, ovvero: la struttura proprietaria, il Consiglio di Amministrazione e l'executive compensation. Per ciascun fattore, si descrivono le caratteristiche tradizionali e attuali.

Parole chiave: corporate governance, Italia, diritto societario, Codice di Autodisciplina.

${ }^{*}$ Full Professor in Corporate Strategy, University of Rome Guido Carli LUISS. azattoni@luiss.it

Corporate Governance and Research \& Development Studies, 1-2019, ISSN 2704-8462 


\section{Introduction}

The Italian corporate governance model has been traditionally characterized by few listed companies, low investor protection, high ownership concentration in the hands of families and the State, the use of control enhancing mechanisms to amplify the divergence between ownership and control, and the influence of large blockholders on the appointment and behavior of board members and top managers (Zattoni, 2015). These characteristics have been stable for a long period and led scholars to summarize the Italian governance model with the expression 'weak managers, strong blockholders and unprotected minority shareholders' (Melis, 2000: 354).

In the last decades, the Italian governance model evolved and became more similar to the Anglo-American one. This evolution is the result of the pressure of external forces pushing to the convergence with international best practices (e.g., EU harmonization of corporate law, codes developed by international organizations like OECD and IMF, foreign institutional investors) and the path dependence characterizing corporate governance models (e.g., because of the interests of large blockholders, and of the inertia of law and ownership structures in place).

In this study, we explore the recent evolution of the Italian governance model, in order to better understand the triggers and the consequences for all stakeholders. In more details, we start highlighting the evolution of the national regulatory environment, in term of both corporate law and good governance code. Then we focus on three key elements of the corporate governance of Italian listed companies, i.e., the ownership structure, the board of directors, and the executive compensation. For each element, we present their traditional and current characteristics.

\section{The evolution of the national regulatory environment}

\section{The evolution of corporate law}

Corporate law (also called hard law) evolves slowly over time. After the commercial code of 1882, there have been two major revisions in 1942 and 2003. The commercial code issued in 1882 provides an advanced regulation of limited liability companies and introduces the board of statutory auditors to monitor both company's management and accounts on behalf of investors. After a long debate on its shortcomings to manage some emerging phenomena (e.g., company groups, cross-shareholdings, control enhancing mechanisms), the legislator issued a new code in 1942. 
However, the 1942 reform almost ignores the separation between ownership and control concerning listed companies and so does not satisfactorily address corporate governance and the protection of minorities. The reform of corporate governance of listed companies is so introduced later, in 1974. The 1974 reform seeks to implement the investor protection principle through a number of regulatory innovations like: (i) the possibility to offer minorities financial instruments (like convertible bonds and shares with no or limited voting rights) more aligned with their pure economic interests; (ii) the establishment of the Securities and Exchange Commission (Consob) with competencies on corporate disclosure and stock trading; (iii) the imposition of disclosure duties and the obligation to appoint outside auditors to certify listed companies' financial statements.

As the 1974 reform did not touch the corporate governance of listed companies, several amendments and revisions have been added in the following years to keep national regulation aligned with international best practices. For example, insider trading is prohibited and investment companies (SIM, Società di Investimento Mobiliare) replace individual stockbrokers in 1991; takeovers are regulated and a mandatory rule is introduced to protect minority shareholders in 1992; the Italian Stock Exchange - i.e., the Milan stock exchange - becomes a for-profit company and its shares are sold to banks and investment firms in 1998.

A radical revision on the regulation concerning investment intermediaries and markets is incorporated into the Financial Markets Consolidated Act promulgated in 1998. The Act introduces new rules about listed companies' disclosure and governance: e.g., it strengthens the powers and responsibilities of the board of statutory auditors, reinforces minority shareholders' powers (e.g., they elect one of the auditors, or two if the board consists of 5 members), promotes corporate control contestability (e.g., it allows members of shareholders' agreements to withdraw in case of a public offer) (Ferrarini, 2005). The reform strengthens investor protection: the anti-director rights index (La Porta et al., 1999) moves from one to five (out of six) (Aganin and Volpin, 2003). The reform also creates a legal environment that is more favorable to institutional investor activism than before (Ventoruzzo, 2005).

As the 1998 reform widened the regulatory differences between listed and unlisted companies, a general reform of corporate law is enacted in 2003 and becomes effective the 1st of January 2004. The new regulation increases the freedom of contract, strengthens the protections for minority shareholders, and imports principles and rules developed in other countries. The main innovations regard the financing of the corporation (e.g., by introducing the possibility to issue shares with different voting and cash-flow rights), the protection of minority shareholders (e.g., by regulating withdrawal rights, 
derivative suits against directors, and business groups), and corporate governance (e.g., by revising shareholders' agreements and introducing two additional models of administration and control - i.e., the unitary or one tier and the dualistic or two-tier model) (Ventoruzzo, 2005). In the following years, the inertia in the adoption of the traditional model underlines how strong may be the path dependency in corporate governance practices (Bebchuk and Roe, 1999). At the end of 2017, only 2 listed companies adopted the unitary (monistic or one tier) model and other 2 adopted the dualistic (or two-tier) model.

Some financial frauds and scandals - e.g., Parmalat, Cirio, and Giacomelli - at the beginning of the new millennium highlight that corporate governance and disclosure rules, despite their increasing convergence towards international best practices, are insufficiently enforced (Ferrarini, 2005). This determined the failure of both internal controls (e.g. board of directors and board of statutory auditors) and external controls (e.g. external auditors, banks, and rating agencies) (Melis, 2005).

As a reaction, the Italian Government issues an Investors Protection Act (the so-called Legge sul Risparmio), aimed at enhancing investors' protection, the accountability of company directors and officers, and the reliability of financial information of listed companies. The Act modifies several rules regarding minority shareholders' rights and corporate governance of listed companies to restore investors' confidence in the Italian capital markets. The new rules amend a number of provisions of Italian financial and corporate laws relating to several matters such as: (i) the appointment and composition of directors (e.g., by introducing the slate voting allowing minority investor to nominate at least one board member and imposing one independent director in boards with more than seven members); (ii) the appointment and composition of statutory auditors (e.g., by increasing their independence from directors and imposing that the chairperson is elected among the members appointed by minorities); (iii) the power of minority shareholders (e.g., reducing the threshold to initiate derivative suits against directors or allowing them to add items to the shareholders' meetings); (iv) the disclosure obligations (including directors' stock option plans, merger between unlisted and listed companies, the compliance with codes of good governance, and subsidiaries located in blacklisted jurisdictions) and the responsibility for preparing financial information; (v) the appointment and dismissal of external auditors, and the range of non-audit services they can provide; and (vi) the criminal penalties associated with the violation of these laws (Zattoni, 2009).

The reforms continue until recently. In 2010, Consob regulates related party transactions and introduces stricter disclosure and procedural requirements (e.g., Italian listed companies are required to publish an annual 
compensation report). In 2011, the government introduces a quota law requiring a minimum representation of one third (one fifth for the first term) of the least represented gender for both listed and state-owned companies, for the following three-terms. In 2014, the government introduces loyalty shares, i.e., companies are allowed to change their by-law granting double voting rights to shareholders owning the shares for at least two years. In 2018, the adoption of the EU directive (2014/95) increases the disclosure on corporate social responsibility by requiring listed companies to publish a non-financial report on social and environmental issues. In June 2019, the implementation of the revision of the Shareholders' Rights Directive (SHRD II) is aimed at encouraging long-term shareholders' engagement. The EU directive imposes the identification of shareholders to facilitate communication with the company and the exercise of shareholders' rights; moreover, it proposes a mandatory vote of the shareholder meeting in relation to the remuneration policy at least every three years or when the board changes the policy.

\section{The good governance code}

In the last decades, the corporate governance of Italian listed companies has been strongly influenced by the development and revision of the national code of best practices. The committee for corporate governance introduces the code in 1999 and then revised and updated it several times (in 2002, 2006, $2010,2011,2014,2015$, and 2018). The code of best practices does not contain compulsory rules but provides good governance recommendations that listed companies are encouraged to follow. In other words, listed companies can either comply with codes' recommendations or explain to shareholders and the Italian stock exchange the reasons for the (total or partial) deviation (i.e., the so-called freedom with accountability principle).

The committee for corporate governance - chaired by Stefano Preda (chairperson of Borsa Italiana at that time) and composed by distinguished representatives of the Italian industrial and financial community - develops a good governance code inspired by international best practices and adapted to take into account the specific characteristics of the Italian institutional environment. The 1999 code specifies the tasks of the board of directors, defines directors' duties and responsibilities, underlines the importance to nominate reputed and competent non-executive and independent directors, identifies the chairperson's responsibilities, emphasizes the relevance of an adequate and timely board information flow, highlights the necessity to adopt transparent procedures for the election of directors and statutory auditors, 
and invites to set up a remuneration and control (or audit) committee with a majority of non-executive directors.

The code has several merits as it promotes a debate on good governance practices, imports international best practices, and influences - at least formally - the corporate governance of Italian listed companies. At the same time, it has been criticized because of the lack of a substantial impact on corporate governance practices due to its relatively vague and broad principles (e.g., 'conscientious self-assessment of directors', 'balanced composition of the board'), the acceptance of traditional national corporate governance practices (e.g., an executive chairperson, the lack of a nomination committee, the absence of independent directors in committees), and the weaknesses of market forces that should promote a substantial adoption of code's best practices (because of high ownership concentration, strong links between banks and mutual funds).

In 2002, after few years from the introduction of the code, its content is revised to keep it in line with both the national regulation and the international best practices. The revision of the code enlarges the definition of independent directors, entrusts the board to assess directors' independence, reinforces governance practices for companies controlled by another listed company, strengthens the procedures for internal handling and disclosure of private information to third parties, better specifies the responsibilities of the remuneration and audit committee, emphasizes the importance of the internal control system, and imposes procedural and substantial fairness on related party transactions. The 2002 revision of the code has the merit to reinforce the internal control system, the board independence, boards' remuneration and audit committees, the mechanisms aimed at preventing directors' conflict of interests in business groups. At the same time, it relies on directors' discretion and does not establish clear and objective limits (e.g., in terms of number of other board memberships or criteria to assess directors' independence).

In 2006, a second and more substantial revision recommends boards to formally evaluate (at least once a year) their size, composition, and performance, to introduce the lead independent director, to evaluate annually directors' independence, to reinforce the functions and the composition of internal committees, to strengthen the independence and the functions of the board of statutory auditors, to adapt codes' recommendations in companies with a dualistic or a monistic model of board of directors.

In the following years, new revisions of the code are issued. After a partial revision of the article 7 regarding directors' compensation in 2010, a new version of the code is published in 2011 to simplify principles, align recommendations with the evolution of the international and national 
regulatory framework, and raise national good governance practices. The major changes regard a better specification of the chairperson role (e.g., in providing timely and comprehensive information), the board composition (e.g., by emphasizing directors' adequate competence and professionalism), the lead independent directors' role (e.g., should collaborate with the chairperson to guarantee timely and comprehensive information, the board role and functioning, the organization and role of board committees. The revision has the merit to discriminate its recommendations between large and small companies, to strengthen the centrality of the board of directors and to redesign the controls and risk management system (Melis and Zattoni, 2017).

After a minor revision in 2014, that affected mostly few recommendations about executive directors' compensation (like disclosing reasons behind the assignment of indemnities at the termination of the employment relationship or introducing claw-back clauses aimed at reclaiming variable compensation under certain conditions), a more profound revision is issued in 2015. The new version encourages boards to pay attention to medium long-term risks and to strengthen the control and risk management system. The code devotes a particular attention to FTSE-Mib companies, whose boards should introduce whistleblowing provisions and evaluate whether to establish a corporate social responsibility committee.

The last revision of the code, issued in 2018, introduces some further changes: it invites companies to apply diversity criteria to board composition, and particularly gender diversity criteria (i.e., having, at least, one third of directors from the least represented gender) to both board of directors and board of statutory auditors.

In sum, both the Italian corporate law and the good governance code have largely evolved in the last decades, especially since the new millennium (see table 1). These reforms - whose major drivers have been both the harmonization of corporate law in EU countries and the pressure of foreign institutional investors and organizations - were aimed at increasing investor protection and aligning national governance practices to international best practices. At the end of such a prolonged and radical reforms, the national regulatory institutional framework is aligned with international best practices (Melis and Zattoni, 2017). 
Table 1 - The most important regulatory reforms affecting listed companies in Italy

\begin{tabular}{|c|c|}
\hline Year & Reform \\
\hline 1974 & - Reform of Italian listed companies \\
\hline 1975 & - Requirement of external auditing of the financial statements \\
\hline 1983 & $\begin{array}{l}\text { - Open-end mutual funds are allowed to operate and are subject to Consob's } \\
\text { supervision }\end{array}$ \\
\hline 1991 & - Regulation of institutional investors \\
\hline & $\begin{array}{l}\text { - Introduction of a European directive on the requirement of consolidated fi- } \\
\text { nancial statements for groups } \\
\text { - Regulation of insider trading }\end{array}$ \\
\hline 1992 & - New regulatory framework for takeover bids \\
\hline 1993 & $\begin{array}{l}\text { - Authorization to the creation of closed-end funds } \\
\text { - New Law on Banks }\end{array}$ \\
\hline 1998 & $\begin{array}{l}\text { - Financial markets consolidated act } \\
\text { - New takeover regulation } \\
\text { - Privatization of the stock markets } \\
\text { - Birth of Borsa Italiana }\end{array}$ \\
\hline 1999 & - Corporate governance code \\
\hline 2002 & - Revision of the corporate governance code \\
\hline 2003 & - Increased disclosure of related-party transactions \\
\hline 2005 & - Corporate law reform \\
\hline 2006 & - Revision of the corporate governance code \\
\hline 2007 & $\begin{array}{l}\text { - Implementation of Takeover Bids EU Directive } \\
\text { - Minority shareholders' representation in the board of directors is mandated }\end{array}$ \\
\hline 2010 & $\begin{array}{l}\text { - Stricter related-party transaction rules } \\
\text { - Revision of article } 7 \text { of the corporate governance code }\end{array}$ \\
\hline 2011 & $\begin{array}{l}\text { - Revision of the corporate governance code } \\
\text { - Gender quotas in the boards }\end{array}$ \\
\hline 2012 & $\begin{array}{l}\text { - Enhanced disclosure on compensation policy and design } \\
\text { - Say on pay on compensation policy }\end{array}$ \\
\hline 2014 & $\begin{array}{l}\text { - Revision of the corporate governance code } \\
\text { - Introduction of loyalty shares }\end{array}$ \\
\hline 2015 & - Revision of the corporate governance code \\
\hline 2018 & $\begin{array}{l}\text { - Revision of the corporate governance code } \\
\text { - Adoption of the EU directive (2014/95) }\end{array}$ \\
\hline 2019 & - Shareholders' Rights Directive (SHRD II) \\
\hline
\end{tabular}

\section{The ownership structure of Italian companies}

\section{The ownership structure of large Italian companies}

The stock market has traditionally played a limited role in the Italian economic system. However, over the last few decades, this situation has partially changed. The number of listed companies in regulated markets is in fact increased significantly (from 140 to 244 companies) between 1960 and 2018 (see table 2). Including also the 113 companies listed in multilateral trading 
facilities, the total number of listed companies equals to 357 . A bit more than 350 companies - out of a total of more than 4.5 million companies - are listed on the stock exchange and market capitalization is around 26 percent of national GDP. Among the reasons that help to explain this situation there are: (i) the tax advantage of debt over equity, thanks to the deductibility of the interest expenses; (ii) the willingness of entrepreneurs to not disclose relevant information to the financial market and to maintain a firm control over the company; (iii) the costs of the listing and of the compliance activity connected to it (Zattoni and Mosca, 2012).

The ownership structure of Italian listed companies is particularly concentrated (Zattoni, 2009). Consob data indicate that, at the end of 2017, the main shareholder holds 47.7 percent of the ordinary shares, the other shareholders (holding more than 2 percent) together hold 12.0 percent, while minority shareholders (holding less than 2 percent) hold the remaining 40.4 percent. As far as the control structure, the percentage of companies controlled with more than 50 percent of the voting rights is slightly reducing from 31.2 percent to 29.8 percent. At the same time, the percentage of companies controlled with less than 50 percent of the shares almost doubles, moving from 21.8 percent to 39.8 percent, while that one of companies controlled by syndicate agreements decreases from 8.3 percent to 5.3 percent. Table 3 indicates that, despite a trend towards greater contestability of control, the vast majority of Italian listed companies (74.9 percent) is still under the influence of a controlling shareholder.

Table 2 - Number of companies and shares listed on the Milan Stock Exchange (1960-2018)

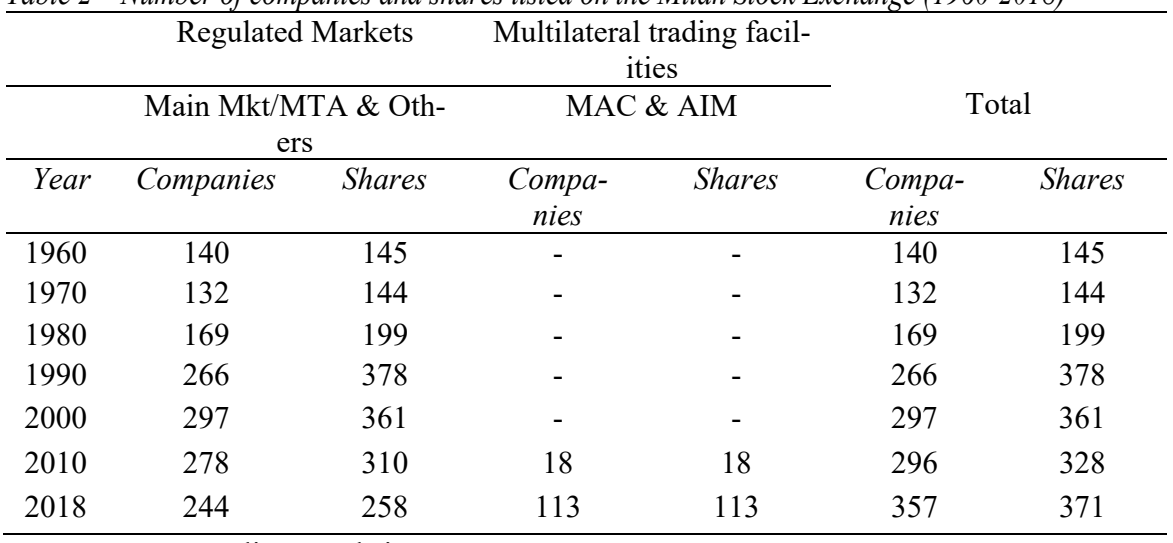

Source: Borsa Italiana, website. 
The ownership structure of Italian listed companies is particularly concentrated (Zattoni, 2009). Consob data indicate that, at the end of 2017, the main shareholder holds 47.7 percent of the ordinary shares, the other shareholders (holding more than 2 percent) together hold 12.0 percent, while minority shareholders (holding less than 2 percent) hold the remaining 40.4 percent. As far as the control structure, the percentage of companies controlled with more than 50 percent of the voting rights is slightly reducing from 31.2 percent to 29.8 percent. At the same time, the percentage of companies controlled with less than 50 percent of the shares almost doubles, moving from 21.8 percent to 39.8 percent, while that one of companies controlled by syndicate agreements decreases from 8.3 percent to 5.3 percent. Table 3 indicates that, despite a trend towards greater contestability of control, the vast majority of Italian listed companies (74.9 percent) is still under the influence of a controlling shareholder.

Table 3 - Control structure of companies listed on the MTA (at the end of each year)

\begin{tabular}{|c|c|c|c|c|c|c|c|c|c|c|c|c|c|c|}
\hline & \multicolumn{6}{|c|}{ Controlled companies } & \multicolumn{6}{|c|}{ Non-controlled companies } & \multicolumn{2}{|c|}{ Total } \\
\hline & \multicolumn{2}{|c|}{$\begin{array}{c}\text { Majority } \\
\text { Controlled } \\
\text { (more than } \\
50 \% \\
\text { of shares) }\end{array}$} & \multicolumn{2}{|c|}{$\begin{array}{c}\text { Weakly } \\
\text { controlled } \\
\text { (less than } \\
50 \% \\
\text { of shares) }\end{array}$} & \multicolumn{2}{|c|}{$\begin{array}{c}\text { Con- } \\
\text { trolled by } \\
\text { a } \\
\text { Share- } \\
\text { holders' } \\
\text { agree- } \\
\text { ment }\end{array}$} & \multicolumn{2}{|c|}{$\begin{array}{l}\text { Coopera- } \\
\text { tive } \\
\text { compa- } \\
\text { nies }\end{array}$} & \multicolumn{2}{|c|}{$\begin{array}{c}\text { Widely } \\
\text { Held }\end{array}$} & \multicolumn{2}{|c|}{$\begin{array}{c}\text { Non- } \\
\text { widely } \\
\text { held }\end{array}$} & & \\
\hline & $\mathrm{N}$ & $\%$ & $\mathrm{~N}$ & $\%$ & $\mathrm{~N}$ & $\%$ & $\mathrm{~N}$ & $\%$ & $\mathrm{~N}$ & $\%$ & $\mathrm{~N}$ & $\%$ & $\mathrm{~N}$ & $\%$ \\
\hline & . & $\mathrm{m}$ & . & $\mathrm{m}$ & . & $\mathrm{m}$ & . & $\mathrm{m}$ & . & $\mathrm{m}$ & . & $\mathrm{m}$ & . & $\mathrm{m}$ \\
\hline & & ar & & ar & & ar & & ar & & ar & & ar & & ar \\
\hline & & ke & & ke & & $\mathrm{ke}$ & & ke & & ke & & ke & & $\mathrm{ke}$ \\
\hline & & $\mathrm{t}$ & & $\mathrm{t}$ & & $\mathrm{t}$ & & $\mathrm{t}$ & & $\mathrm{t}$ & & $\mathrm{t}$ & & $\mathrm{t}$ \\
\hline & & $\mathrm{C}$ & & $\mathrm{ca}$ & & $\mathrm{ca}$ & & ca & & $\mathrm{ca}$ & & ca & & $\mathrm{ca}$ \\
\hline & & ap & & $\mathrm{p}$ & & $\mathrm{p}$ & & $\mathrm{p}$ & & $\mathrm{p}$ & & $\mathrm{p}$ & & $\mathrm{p}$ \\
\hline 19 & 1 & 3 & 3 & 2 & 2 & 8. & 1 & 3. & 1 & 2 & 1 & 1 & 2 & 1 \\
\hline 98 & 2 & 1. & 3 & 1. & 8 & 3 & 0 & 1 & 0 & 4. & 3 & 1 . & 1 & 0 \\
\hline & 2 & 2 & & 8 & & & & & & 1 & & 5 & 6 & 0 \\
\hline 20 & 1 & 2 & 5 & 4 & 5 & 1 & 8 & 3. & 1 & 2 & 1 & 0 . & 2 & 1 \\
\hline 10 & 2 & 0. & 3 & 3. & 1 & 2. & & 4 & 1 & 0. & 9 & 3 & 7 & 0 \\
\hline & 8 & 6 & & 3 & & 4 & & & & 3 & & & 0 & 0 \\
\hline 20 & 1 & 2 & 5 & 3 & 2 & 5. & 2 & 0 . & 1 & 2 & 1 & 1. & 2 & 1 \\
\hline 17 & 2 & 9. & 7 & 9. & 2 & 3 & & 5 & 6 & 3. & 4 & 1 & 3 & 0 \\
\hline & 0 & 8 & & 8 & & & & & & 5 & & & 1 & 0 \\
\hline
\end{tabular}

Source: Consob (2019).

Table 4 underlines that the identity of the ultimate shareholder, i.e., of the shareholder who has the control of the company at the top of the group, differs across the different market segments. Families and State and local authorities are the first category among largest companies (FTSE MIB). However, if we look at the entire sample, families are by far the most common controlling shareholder in all market segments (mid cap, star, other), while the State and local authorities mostly control large companies in public utilities. Financial institutions play a relatively minor role as they control only 
14 companies, most of them listed in other markets. Mixed ownership, i.e., coalitions of different types of shareholders, control 7 companies. Finally, it is interesting to note that a relatively large number of companies (i.e., 42) is without a controlling shareholder: they operate above all in financial services and are cooperatives, widely held companies, and companies controlled by a non-controlled company.

Table 4 - Ultimate shareholder identity in listed companies (at the end of 2017)

\begin{tabular}{|c|c|c|c|c|c|c|c|c|c|c|}
\hline & \multicolumn{2}{|c|}{ FTSE MIB } & \multicolumn{2}{|c|}{ Mid Cap } & \multicolumn{2}{|c|}{ Star } & \multicolumn{2}{|c|}{ Other } & \multicolumn{2}{|c|}{ Total } \\
\hline & $N$. & $\begin{array}{c}\text { weigh } \\
t\end{array}$ & $N$. & $\begin{array}{c}\text { weigh } \\
t\end{array}$ & $N$. & $\begin{array}{c}\text { weigh } \\
t\end{array}$ & $N$. & $\begin{array}{c}\text { weigh } \\
t\end{array}$ & $N$. & $\begin{array}{c}\text { weigh } \\
t\end{array}$ \\
\hline $\begin{array}{l}\text { Fami- } \\
\text { lies }\end{array}$ & $\begin{array}{l}1 \\
0\end{array}$ & 29.4 & $\begin{array}{l}2 \\
2\end{array}$ & 59.5 & $\begin{array}{l}5 \\
0\end{array}$ & 69.4 & $\begin{array}{l}6 \\
3\end{array}$ & 71.6 & $\begin{array}{c}14 \\
5\end{array}$ & 62,8 \\
\hline $\begin{array}{l}\text { State } \\
\text { and } \\
\text { local } \\
\text { au- } \\
\text { thori- } \\
\text { ties }\end{array}$ & $\begin{array}{l}1 \\
0\end{array}$ & 29.4 & 6 & 16.2 & 3 & 4.2 & 4 & 4.5 & 23 & 10,0 \\
\hline $\begin{array}{l}\text { Fi- } \\
\text { nan- } \\
\text { cial } \\
\text { insti- } \\
\text { tu- } \\
\text { tions }\end{array}$ & 0 & 0.0 & 2 & 5.4 & 3 & 4.2 & 9 & 10.2 & 14 & 6,1 \\
\hline $\begin{array}{l}\text { Mixe } \\
\text { d }\end{array}$ & 1 & 2.1 & 1 & 2.7 & 3 & 4.2 & 2 & 2.3 & 7 & 3,0 \\
\hline $\begin{array}{l}\text { With- } \\
\text { out } \\
\text { con- } \\
\text { trol- } \\
\text { ling } \\
\text { share- } \\
\text { holde } \\
\text { r }\end{array}$ & $\begin{array}{l}1 \\
3\end{array}$ & 34.7 & 6 & 16.2 & $\begin{array}{l}1 \\
3\end{array}$ & 18,1 & $\begin{array}{l}1 \\
0\end{array}$ & 11.4 & 42 & 18,2 \\
\hline
\end{tabular}

Another important characteristic of the ownership structure is the presence of minority institutional investors, here defined as the investment funds, banks and insurance companies whose shareholdings are lower than 10 percent (see table 5). The presence of these investors is decreasing over time, as at the end of 2017 they hold a mean shareholding of 7.7 (8.0 in 2010) in 60 listed companies (78 in 2010). At the same time, the trend differs between Italian and foreign institutional investors. The Italian institutional investors largely decrease the number of companies in which they hold a stake (from 47 to 10) while at the same time they slightly increase their mean shareholding (from 6.8 to 7.6). The foreign institutional investors, instead, increase the number of companies in which they invest (from 39 to 51) while they slightly decrease the mean shareholding (from 7.7 to 7.3). These numbers hide some 
further characteristics of institutional investors: the Italian ones invest more in mid cap and service companies, while the foreign ones invest more in large financial and industrial companies.

Table 5 - Institutional investors' shareholdings in Italian listed companies

\begin{tabular}{|c|c|c|c|c|c|c|c|c|c|}
\hline & \multicolumn{3}{|c|}{$\begin{array}{c}\text { At least one institutional } \\
\text { investor }\end{array}$} & \multicolumn{3}{|c|}{$\begin{array}{c}\text { At least one Italian insti- } \\
\text { tutional investor }\end{array}$} & \multicolumn{3}{|c|}{$\begin{array}{c}\text { At least one foreign insti- } \\
\text { tutional investor }\end{array}$} \\
\hline & $N$. & weight & $\begin{array}{c}\text { Mean } \\
\text { share- } \\
\text { hold- } \\
\text { ing }\end{array}$ & $N$ & weight & $\begin{array}{c}\text { Mean } \\
\text { share- } \\
\text { hold- } \\
\text { ing }\end{array}$ & $N$. & weight & $\begin{array}{c}\text { Mean } \\
\text { share- } \\
\text { hold- } \\
\text { ing }\end{array}$ \\
\hline 2010 & 78 & 28.9 & 8.0 & 47 & 17.4 & 6.8 & 39 & 14.4 & 7.7 \\
\hline 2017 & 60 & 26.0 & 7.7 & 12 & 5.2 & 7.6 & 51 & 22.1 & 7.3 \\
\hline
\end{tabular}

Source: Consob, 2019.

A traditional characteristic of Italian listed companies has been the use of control enhancing mechanisms to separate ownership (i.e., cash-flow rights) and control (i.e., voting rights). One of the most common mechanisms used in the past was the pyramidal group, i.e., a group of companies consisting of one parent or holding company at the top, few or several operating companies at the bottom, and various intermediate levels of financial sub holdings (Zattoni, 1999). Table 6 shows that horizontal groups (i.e., listed companies controlled by an unlisted company) and, above all, pyramidal groups (i.e., one listed company controlling at least another listed company) decrease considerably over time. At the same time, mixed groups (i.e., groups combining the characteristics of horizontal and pyramidal groups) and, above all, stand-alone companies increase consistently over time.

About shares with no, limited or multiple votes, Italian listed companies have traditionally issued shares without (i.e., savings shares) or with limited (i.e., preferred shares) voting rights. This mechanism - together with pyramidal groups - allows controlling shareholders to reduce the amount of financial resources necessary to control the company. In the past, several companies issued these shares, but in the last decades they almost disappeared since they did not satisfy both the interests of the controlling shareholders, because of the higher dividends to compensate the limitation of voting rights, and of the minority shareholders, because their market value had a large discount on ordinary shares with full voting rights. Since 2015, the Italian law allows listed companies to introduce in their bylaw loyalty shares (i.e., shares granting double voting rights to shareholders owning the shares for at least two years), and unlisted companies to issue multiple voting shares (i.e., shares with enhanced voting rights up to a maximum of three votes per share) that may be kept after the IPO (Ventoruzzo, 2015). Table 6 shows that while loyalty shares are quite diffused, especially among industrial companies listed in the star market, the use of multiple voting shares is relatively rare. 
Table 6-Control enhancing mechanisms in Italian listed companies

\begin{tabular}{|c|c|c|c|c|c|c|c|c|}
\hline & \multicolumn{4}{|c|}{ Corporate groups } & \multicolumn{4}{|c|}{$\begin{array}{c}\text { Shares with no, limited or multiple } \\
\text { votes }\end{array}$} \\
\hline & $\begin{array}{l}\text { Hori- } \\
\text { zontal }\end{array}$ & $\begin{array}{c}P y- \\
\text { rami- } \\
\text { dal }\end{array}$ & Mixed & $\begin{array}{l}\text { Stand- } \\
\text { alone } \\
\text { compa- } \\
\text { nies }\end{array}$ & $\begin{array}{l}\text { Sav- } \\
\text { ings }\end{array}$ & $\begin{array}{c}\text { Pre- } \\
\text { ferred }\end{array}$ & $\begin{array}{l}\text { Loy- } \\
\text { alty }\end{array}$ & $\begin{array}{c}\text { Mul- } \\
\text { tiple } \\
\text { vot- } \\
\text { ing } \\
\end{array}$ \\
\hline 1998 & 5.1 & 36.1 & 2.8 & 56.0 & 69 & 10 & n.a. & n.a. \\
\hline 2010 & 4.4 & 15.6 & 4.4 & 75.6 & 36 & 5 & n.a. & n.a. \\
\hline 2018 & 0 & 12.1 & 6.5 & 81.4 & 17 & 0 & 41 & 3 \\
\hline
\end{tabular}

Source: Consob, 2019.

Finally, the ownership structure of Italian large listed companies has been characterized by intercompany shareholdings, created thanks to the financial advice of Mediobanca, the most important investment company in the country (Zattoni and Cuomo, 2016). For several decades, Mediobanca played the role of white squire, i.e., of a bank that helped entrepreneurial families to keep the control of large companies without large investments. The mutual shareholdings were equal to, and sometimes also greater than, the shareholdings owned by the wealthy entrepreneurial family controlling the business group. The alliance between the controlling shareholders and Mediobanca was usually formalized by signing shareholders' voting or blocking agreements, i.e., agreements that, respectively, bound shareholders to vote together or prevented them from selling their shares to other investors (Zattoni, 1999). The web of mutual shareholdings was also favoring the diffusion of interlocking directorships, aimed at reinforcing the alliance. In the last decades, the percentage of companies involved by cross-shareholdings decreased significantly, also because of the diminished influence of Mediobanca on Italian capitalism. As a result, table 7 shows that the equity links across large private business groups are becoming less pervasive and important than in the past (Bianchi and Bianco, 2008).

Table 7 - Cross-ownership in listed companies

\begin{tabular}{llccc}
\hline & & 1990 & 1998 & 2007 \\
\hline $\begin{array}{l}\text { Companies in- } \\
\text { volved }\end{array}$ & N. of companies & 14.5 & 11.1 & 7.0 \\
$\begin{array}{l}\text { Ownership } \\
\text { links (1) }\end{array}$ & 39.3 & 30.6 & 23.5 \\
\hline Total & Number of links & 56.0 & 57.0 & 40.0 \\
\hline
\end{tabular}

Note: (1) ownership links between listed companies belonging to groups which are both participating in others listed groups and participated by other listed groups.

Source: Bianchi and Bianco (2008). 
Taken together, Consob data and recent empirical studies (e.g., Bianchi and Bianco, 2008; Cuomo, Zattoni, and Valentini, 2013; Mengoli, Pazzaglia and Sapienza 2009; Zattoni and Cuomo, 2015) support the idea that the ownership structure of Italian listed companies is highly concentrated and quite stable over time. The main shareholders are usually represented by wealthy entrepreneurial families, and in fewer cases by the State and local authorities or financial institutions. The institutional investors do not play, in general, a governance role. However, while the Italian institutional investors are reducing their weight on Italian listed companies, the foreign ones are increasing their shareholdings and influence. The use of traditional control enhancing mechanisms (i.e., pyramidal groups and shares with limited or no voting rights) is decreasing over time. As a consequence, the separation (or the wedge) between control and cash flow rights is also diminishing. This happens despite some new control enhancing mechanisms (like loyalty shares) are rapidly diffusing among listed companies.

In sum, coherently with the so-called law and finance perspective (La Porta et al., 1998), the increase in the investor protection and the adoption of international best practices contributed to decrease the use of CEMs - e.g., pyramidal groups and limited voting shares - and the separation between control and cash flow rights. At the same time, the ownership structure remains relatively concentrated in the hands of wealthy entrepreneurial families, thanks also to the use of new control enhancing mechanisms (e.g., loyalty and multiple voting shares).

\section{The Board of Directors of Italian companies}

The characteristics of the board of directors of Italian companies before the introduction of the code

In the Italian traditional governance model, shareholders elect both a board of directors and a board of statutory auditors. The board of directors plays three key roles: the strategic role (i.e., it establishes vision and mission, revise, approve or reject the strategic plan and major strategic decisions), the control role (i.e., it monitors firm performance, risk level, top management behavior, and compliance with law), and the networking role (i.e.. it legitimizes the firm, increases its reputation, and create a link with key stakeholders). The board of statutory auditors monitors the compliance with the law and the by-law, the application of principles of correct administration and the adequacy of the organizational, administrative and accounting structure and its actual functioning. The auditing of company's accounts is carried out by an auditing firm appointed by the shareholders' meeting. 
In the 1990s, some studies on the boards of large Italian companies underlined that they were dominated by insiders (i.e., company managers, controlling shareholders, or persons linked to them by family ties or professional relationships) and the presence of non-executive directors was limited and mainly aimed at increasing the company's reputation among stakeholders. In these circumstances, the executive committee usually absorbed the board's responsibilities. Moreover, the board did not perform effectively its roles because of the small number of meetings, the lack of a formalization and evaluation of directors' role, and the insufficient (and filtered by managers) information flow to directors (Crisci and Tarizzo, 1994).

\section{The characteristics of the board of directors of Italian companies after the} introduction of the code

Prompted by the Cabdury code and the diffusion of good governance codes, the Italian stock exchange promoted the issue of an Italian code that, together with the evolution of corporate law, changed the characteristics of the boards of directors of Italian listed companies. Based on data provided by Assonime, table 8 synthesizes the key characteristics of the board of directors in 2004, i.e., few years after the first revision of the code, and in 2017.

In 2004, the boards of directors of Italian listed companies presented several improvements respect to the ' $90 \mathrm{~s}$. For example, it was characterized by a good number of meetings with a high attendance by all directors, a majority of non-executive directors, a large diffusion of the remuneration and of the control committees consisting of a majority of non-executive directors. At the same time, the 2002 code was still too weak and so companies were still lagging behind on several aspects like board independence, the diffusion of nomination committees, the independence of board committees, and the introduction of some board processes (like board induction and evaluation).

In 2017, the several revisions of the code and the experience matured by listed companies and investors favored the evolution of boards of directors coherently with international best practices. In particular, the number of meetings and directors' attendance increase, likewise the weight of non-executive and independent directors, several companies adopt the slate voting system and have minority directors, all board committees are more widespread and consist of a majority of independent directors, lead independent directors are appointed when the chairperson is the CEO or a large shareholder, board evaluation and induction become common processes, some companies start to develop top management succession plans.

In a nutshell, the evolution of the characteristics of the board of directors 
of listed and large Italian companies indicates a significant improvement compared to the situation described in the ' 90 s. The introduction of practices aimed at promoting the collegial functioning of the board, the appointment of independent and minority directors, the increasing directors' responsibilities may favor the emergence of an open and effective dialogue among board members. From this perspective, the code played a key role in pushing shareholders, directors, and managers to develop and adopt good corporate governance practices.

However, despite the compliance and alignment with good governance practices, some board characteristics suggest to be cautious about their effectiveness. For example, the lower diffusion of nomination committees may hide the willingness of controlling shareholders to influence the selection of new board members; the limited length of board meetings may indicate the lack of a proper debate and the domination of controlling shareholders or top managers; the limited use of reputed consultants to perform board self-assessment may suggest the will to avoid a proper and objective debate on board effectiveness; the risk that some independent directors formally comply with the code may hide their substantial dependence on powerful corporate actors; and so on.

The previous considerations raise doubts on the efficacy of the good governance code to substantially impact the board practices of Italian listed companies (e.g., Zattoni and Cuomo, 2008 and 2010). First, some of code's recommendations are still too weak respect to international best practices, also because the committee that drafts principles and recommendations consists of large shareholders, directors and managers that may have the interest to slow down the introduction of good governance practices. Furthermore, the prescriptive content of some recommendations (i.e., board independence) can lead companies to comply with them formally (i.e., box ticking), without changing the substance of the corporate governance. Finally, the code focuses on board composition, structure and (partly) functioning as these elements are easily measurable and observable from a distance. However, board effectiveness to fulfill its roles can only be assessed by observing whether the board members work together as a team, are adequately involved in the strategic decision-making process, analyze board decisions with the necessary depth and breadth of information, are able to discuss openly the various items on the agenda avoiding personal conflicts, take profit of all experiences and competencies in the boardroom, etc. (e.g., Zona and Zattoni, 2007; Minichilli, Zattoni, and Zona, 2009). These thoughts suggest that in Italy, like in several other countries with high concentrated ownership, the real effectiveness of the boards of directors depends on the willingness of the controlling shareholders to grant it the necessary autonomy and power. 
Table 8 - The characteristics of the board of directors of Italian listed companies

\begin{tabular}{|c|c|c|}
\hline & 2004 & 2017 \\
\hline Sample & 248 listed companies & 259 listed companies \\
\hline $\begin{array}{l}\text { Board of directors' } \\
\text { meetings }\end{array}$ & $\begin{array}{l}\text { - } 9.4 \text { annual meetings (min } \\
4, \text { max } 31), \text { larger in } \\
\text { banks and insurance } \\
\text { (13.4) and large compa- } \\
\text { nies (12.7) } \\
\text { - } 86 \% \text { of attendance to } \\
\text { board meetings (12 direc- } \\
\text { tors with } 0 \text { meetings) }\end{array}$ & $\begin{array}{l}\text { - } 11.2 \text { annual meetings (min } 4, \\
\text { max 39), larger in banks }(19.8) \\
\text { and large companies (14.4) } \\
\text { - } 2 \text { hours and } 15 \text { minutes average } \\
\text { length of board meetings (min } 38 \\
\text { minutes, max } 5.6 \text { hours) } \\
\text { - } 92 \% \text { of attendance of board meet- } \\
\text { ings ( } 7 \text { directors with } 0 \text { meetings) } \\
67 \% \text { of boards organize at least } \\
\text { one meeting with only independ- } \\
\text { ent directors }\end{array}$ \\
\hline $\begin{array}{l}\text { Executive committee } \\
\text { meetings }\end{array}$ & $\begin{array}{l}\text { - } 11.4 \text { meetings }(\min 0 \text {, } \\
\max 49)\end{array}$ & $\begin{array}{l}13.6 \text { meetings of the executive } \\
\text { committee }(\min 0, \max 72)\end{array}$ \\
\hline $\begin{array}{l}\text { Board of statutory } \\
\text { auditors' meetings }\end{array}$ & $\begin{array}{l}\text { - } 11.1 \text { meetings }(\min 4 \text {, } \\
\max 55)\end{array}$ & $\begin{array}{l}\text { - } 12.8 \text { meetings }(\min 4, \max 92) \\
\text { - } 2 \text { hours and half average length } \\
\text { - } 96 \% \text { of attendance }\end{array}$ \\
\hline $\begin{array}{l}\text { Other board member- } \\
\text { ships }\end{array}$ & $\begin{array}{l}\text { - } 2.4 \text { other membership } \\
(\min 0, \max 32)\end{array}$ & $\begin{array}{l}2.09 \text { other membership for direc- } \\
\text { tors (min } 0, \max 27) \\
7.78 \text { other membership for statu- } \\
\text { tory auditors }(\min 0, \max 49)\end{array}$ \\
\hline Board composition & $\begin{array}{l}\text { - } 10.1 \text { directors, } 15.4 \text { in } \\
\text { banks } \\
30 \% \text { executive directors, } \\
29 \% \text { non-executive but } \\
\text { not independent direc- } \\
\text { tors, } 41 \% \text { independent di- } \\
\text { rectors } \\
68 \% \text { executive chairper- } \\
\text { son }\end{array}$ & $\begin{array}{l}\text { - } 10 \text { directors, } 15.2 \text { in financial } \\
\text { - } 25 \% \text { executive directors, } 31 \% \\
\text { non-executive but not independ- } \\
\text { ent, } 44 \% \text { independent directors } \\
\text { - } 57 \text { years of average age } \\
\text { - } 6.5 \text { years average tenure: } 10.4 \text { for } \\
\text { executive, } 5.1 \text { non-executive, } 3.9 \\
\text { independent } \\
\text { - } 82 \% \text { has a CEO, } 21 \% \text { CEO dual- } \\
\text { ity } \\
\text { - } 43 \% \text { has a LID }\end{array}$ \\
\hline Slate - voting system & $\begin{array}{l}17 \% \text { of companies adopts } \\
\text { slate voting system for } \\
\text { the board of directors } \\
10 \% \text { of companies has } \\
\text { minority directors ( } 2.8 \\
\text { directors on average) } \\
\text { - } 28 \% \text { of companies has } \\
\text { statutory auditors elected } \\
\text { by minorities ( } 1.2 \text { statu- } \\
\text { tory auditors on average) }\end{array}$ & $\begin{array}{l}46 \% \text { of companies has minority } \\
\text { directors (minority directors } \\
\text { equal to } 183 \text { ) } \\
\text { - } 50 \% \text { of companies has statutory } \\
\text { auditor elected by minorities (mi- } \\
\text { nority statutory auditors equal } \\
112)\end{array}$ \\
\hline Nomination committee & $\begin{array}{l}\text { - } 10 \% \text { of companies } \\
\text { All companies, except } \\
\text { one, have a majority of } \\
\text { non-executives }\end{array}$ & $\begin{array}{l}\text { - } 57 \% \text { of companies, usually in } \\
\text { combination with the remunera- } \\
\text { tion committee } \\
\text { - All companies, except four, have } \\
\text { a majority of independent direc- } \\
\text { tors } \\
\text { - } 86 \% \text { of chairperson are independ- } \\
\text { ent } \\
\text { - } 5.5 \text { meetings per year, lengths is } \\
\text { about } 1 \text { hour } \\
\text { - } 79 \% \text { members attend all meetings }\end{array}$ \\
\hline
\end{tabular}




\begin{tabular}{|c|c|c|}
\hline & 2004 & 2017 \\
\hline $\begin{array}{l}\text { Sample } \\
\text { Remuneration com- } \\
\text { mittee }\end{array}$ & $\begin{array}{l}248 \text { listed companies } \\
\text { - } 70 \% \text { of companies } \\
\text { - All companies, except } \\
\text { one, have a majority of } \\
\text { non-executives } \\
\text { - } 2 \text { meetings per year (min } \\
0, \text { max 19) }\end{array}$ & $\begin{array}{l}\text { 259 listed companies } \\
\text { - } 91 \% \text { of companies } \\
\text { - } 81 \% \text { of committees have three } \\
\text { members } \\
\text { - } 46 \% \text { of committees have only in- } \\
\text { dependent } \\
\text { - } 89 \% \text { of chairperson are independ- } \\
\text { ent } \\
\text { - } 4.7 \text { meetings per year (min } 0, \\
\text { max } 20 \text { ) } \\
\text { - } 71 \text { minutes average length of } \\
\text { meetings } \\
\text { - } 87 \% \text { of members attend all meet- } \\
\text { ings }\end{array}$ \\
\hline $\begin{array}{l}\text { Audit (control and } \\
\text { risk) committee }\end{array}$ & $\begin{array}{l}\text { - } 77 \% \text { of companies } \\
\text { - All companies, except } 1 \text {, } \\
\text { have a majority of non- } \\
\text { executive directors } \\
\text { - } 4-5 \text { meetings per year } \\
(\text { min } 0, \text { max } 19)\end{array}$ & $\begin{array}{l}\text { - } 95 \% \text { of companies } \\
\text { - } 78 \% \text { of committees have three } \\
\text { members } \\
\text { - } 57 \% \text { of committees have only in- } \\
\text { dependent } \\
\text { - } 95 \% \text { of chairperson are independ- } \\
\text { ent } \\
\text { - } 7.7 \text { meetings per year (min } 1 \text {, } \\
\text { max } 36 \text { ) } \\
\text { - } 116 \text { minutes average length of } \\
\text { meetings } \\
\text { - } 77 \% \text { of members attend all meet- } \\
\text { ings }\end{array}$ \\
\hline Board evaluation & - Not available & $\begin{array}{l}\text { - } 80 \% \text { of companies perform an } \\
\text { annual evaluation of the board } \\
\text { - } 30 \% \text { of companies use consult- } \\
\text { ants } \\
\text { - } 37 \text { companies evaluate also indi- } \\
\text { vidual directors }\end{array}$ \\
\hline Board induction & - Not available & $\begin{array}{l}\text { - } 97 \% \text { FTSE Mib, } 86 \% \text { Mid cap, } \\
59 \% \text { small cap }\end{array}$ \\
\hline Succession plans & - Not available & - 35 companies \\
\hline
\end{tabular}

Source: Assonime, 2004 and 2018.

\section{The executive compensation in Italian listed companies}

The empirical evidence on executive compensation in Italy between the '80s and the '90s shows that managers received a fixed compensation, a short-term bonus and some benefits. At that time, long-term equity incentives were rarely used by few large private industrial groups, multinational subsidiaries and holding companies to reduce the managerial labor cost, reward top managers for the results achieved, and highlight the role of senior management within the company. 
Equity incentives started to be adopted on a large scale only at the beginning of 2000 (e.g., Airoldi and Zattoni, 2001; Zattoni, 2003). At that time, their diffusion has been strongly incentivized by the tax reform of the 1st of January 1998, as it provided significant tax benefits to their beneficiaries. More recent empirical evidence confirms that, at least among large listed companies, stock incentive schemes have become an important and stable element of the company's remuneration system. Moreover, the characteristics of the incentive plans show a positive evolution, like (consistently with the evolution of tax regulations) the exercise price is fixed at the average market price in the month preceding the offer, several plans link the right to exercise options to the performance of the share price versus a significant stock market index (e.g., the FTSE Mib or an industry index at national or European level) or a target price set in advance; the length of the vesting and of the exercise period - and the overall length of the incentive plan (i.e. the time horizon from the granting date to the expiring date) - increase over time. The empirical evidence also shows that the equity incentive plans have been used by some companies to camouflage the distribution of high compensation packages to controlling shareholders (e.g., Zattoni, 2007; Zattoni and Minichilli, 2009).

The empirical evidence (Mercurio and Zattoni, 2013) on the compensation of top managers (i.e. CEOs, chairpersons and vice presidents) of nonfinancial companies listed on the Italian stock exchange between 2005-2009 shows that the average compensation of CEOs is just under one million euros. However, figures show a large variance: while some CEOs receive a symbolic compensation of a few thousand euros, other CEOs receive several million euros. Moreover, the distribution of CEO compensation is skewed as the total remuneration received by the first ten CEOs represents 20-30 percent of the compensation of all CEOs. Still, CEO compensation is characterized by the high weight of fixed remuneration and the low weight of variable compensation. Finally, very generous compensation packages, i.e., close to or higher than $€ 10$ million, are usually the result of non-recurring bonuses or the severance pay recorded under "other compensation". This type of remuneration, which captures media's interest for its large amount, is typically a deferred payment for the services provided to the company over a long tenure period. These items raise large concerns both because of their considerable amounts, and because they are often not adequately explained to the market. Consequently, investors are unable to understand the real reasons and criteria behind the total amount paid.

Chairpersons receive a level of compensation similar to CEOs. In particular, their average compensation varies between $€ 500,000$ and $€ 600,000$, with significant differences between executive and non-executive chairpersons. In line with their role, the weight of fixed remuneration is higher, and 
the weight of bonus is lower, than for CEOs. The item "other remuneration" plays a significant role and mainly relates to remuneration for positions held in subsidiaries or affiliated companies. The role of the vice-presidents differs across companies and consequently their remuneration is very heterogeneous. Their average compensation ranges from $€ 300,000$ to $€ 400,000$. Also in this case, it ranges between purely symbolic amounts and large amounts higher than the average CEOs' compensation. Their compensation is more similar to that of CEOs than of chairpersons, indicating that they cover an executive role. Finally, the distribution of vice-presidents' compensation is even more concentrated than that one of chairpersons and CEOs.

The total amount received by senior managers remained relatively stable over the years. In particular, the CEOs with the highest pay or the companies with the highest pay levels have always been more or less the same, underlying a certain inertia or rigidity of the pay system even when company performance changes. This trend is due to the strong weight of the fixed compensation, which is independent from company's performance, and to the presence of bonuses that are substantially rigid.

Latest available empirical evidence supports these results and adds information on the remuneration of independent directors. Table 9 confirms the importance of fixed compensation among top managers, the diffusion of long-term incentive plans, the growing presence of claw-back clauses. These figures also indicate that independent directors receive an average of $€ 56,000$ as board members and may add an additional $€ 15,000-20,000$ if they are members of a committee. Finally, they confirm that compensation is higher and more articulated in large and financial companies.

Table 9 - The remuneration of directors of Italian listed companies

\begin{tabular}{|c|c|}
\hline & 2017 \\
\hline Sample & Listed companies \\
\hline $\begin{array}{l}\text { Compensa- } \\
\text { tion policy }\end{array}$ & $\begin{array}{l}\text { - } 86 \% \text { of companies adopt variable compensation } \\
\text { - } 98 \% \text { of bonuses are linked with accounting measures of perfor- } \\
\text { mance, } 61 \% \text { with strategic objectives, } 51 \% \text { with shares value } \\
\text { - } 88 \% \text { of companies with variables compensation fixed a cap to some } \\
\text { components } \\
\text { - } 94 \% \text { of companies with variable compensation have a short-term bo- } \\
\text { nus, } 76 \% \text { have long-term bonus } \\
\text { - } 51 \% \text { of companies adopt a claw-back clause }\end{array}$ \\
\hline CEO & $\begin{array}{l}\text { - CEO compensation consists of fixed }(54 \%) \text {, bonus }(28 \%) \text {, subsidiar- } \\
\text { ies }(12 \%) \\
\text { - Average compensation equals to } € 918,000 \text {, higher in FTSE Mib and } \\
\text { in financial companies } \\
\text { - } 18 \% \text { of CEOs has stock incentives for an average fair value of } \\
€ 1,068,000\end{array}$ \\
\hline
\end{tabular}




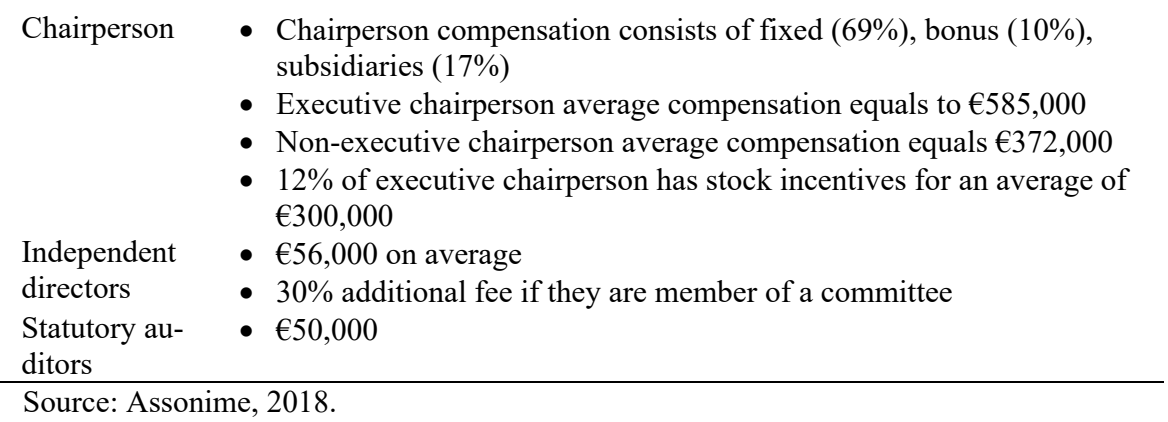

\section{Conclusions}

The evolution of both corporate law and good governance code has strengthened the corporate governance practices of Italian listed companies. The evolution of the regulatory environment has, in fact, promoted several changes in the ownership structure (e.g., a lower use of pyramidal groups and dual class shares, a lower divergence between control and cash-flow rights), the board of directors (e.g., the increase of board independence, the diffusion of board committees, the appointment of lead independent directors, the introduction of board evaluation and induction), the executive compensation (e.g., the diffusion of both short-term and long-term variable compensation, the use of claw back clauses, higher disclosure on compensation packages).

However, an updated regulatory environment may be not able to stimulate the adoption of efficient corporate governance practices, as there is the risk that the form prevails on the substance. Some events - like the inertia to adopt the new models of administration and control and the tendency to formally comply with the recommendations of the good governance code - suggest a defensive rather than proactive attitude, i.e., the search for compliance rather than effective corporate governance practices (Minichilli and Zattoni, 2017).

The recent debate on the purpose of companies highlights that the corporate governance practices should ensure that the governing bodies act in the interest of the company and its stakeholders. To this end, it is not sufficient to create boards of directors - and internal committees - composed of competent and independent persons. It is necessary to develop board processes that enhance the different skills and experiences present in it, create a culture of board accountability, encourage directors to perform their tasks effectively. From this perspective, the evolution of the regulatory environment should be accompanied by both rigorous studies on the diffusion and effectiveness of governance practices, and by training programs emphasizing the importance of investors, directors and top managers' ethical behaviors. 


\section{References}

Aganin A., Volpin P.F. (2003). History of Corporate Ownership in Italy, ECGI Finance Working Paper No. 17. DOI: 10.2139/ssrn.391180

Airoldi G., Zattoni A. (Eds.) (2001). Piani di stock option - Progettare la retribuzione del top management. Milano, Egea.

Assonime (2004), Analisi dello stato di attuazione del codice di autodisciplina delle società quotate.

Assonime (2018), La corporate governance in Italia: autodisciplina, remunerazioni e comply-or-explain.

Bebchuk L.A., Roe M.J. (1999). Theory of path dependence in corporate ownership and governance. Stanford Law Review, 52 (1), 127-170. DOI: 10.2307/1229459

Bianchi M., Bianco M. (2008). The evolution of ownership and control structure in Italy in the last 15 years, working paper.

Consob (2018), Report on corporate governance of Italian listed companies.

Crisci G., Tarizzo G. (1994). Il governo della impresa, Egon Zehnder International and Executive Interim Management.

Cuomo F., Zattoni A., Valentini G. (2013). The Effects of Legal Reforms on the Ownership Structure of Listed Companies. Industrial and Corporate Change, 22(2), 427-58. DOI: 10.1093/icc/dts015

Ferrarini G. (2005). Corporate governance changes in the 20th century: A view from Italy, ECGI, Law working paper, n. 29. DOI: 10.2139/ssrn.695762

La Porta R., Lopez-de-Silanes F., Shleifer A., Vishny R. (1998). Law and Finance. Journal of Political Economy, 106 (6), 1113-55. DOI: 10.1086/250042

La Porta R., Lopez-de-Silanes F., Shleifer A. (1999). Corporate ownership around the world. Journal of Finance, 54, 471-517. DOI: 10.1111/0022-1082.00115

Melis A. (2000). Corporate Governance in Italy. Corporate Governance: An International Review, 8(4), 347-55. DOI: 10.1111/1467-8683.00213

Melis A. (2005). Corporate Governance Failures: to what extent is Parmalat a particularly Italian Case? Corporate Governance: An International Review, 13(4), 478-488. DOI: 10.1111/j.1467-8683.2004.00443.x

Melis A., Zattoni A. (2017). A Primer on Corporate Governance: Italy. New York, Business Expert Press.

Mengoli S., Pazzaglia F., Sapienza E. (2009). Effect of Governance Reforms on Corporate Ownership in Italy: Is It Still Pizza, Spaghetti, and Mandolino? Corporate Governance: An International Review, 17(5), 629-45. DOI: 10.1111/j.14678683.2009.00752.x

Mercurio L., Zattoni A. (2013). La retribuzione dei consiglieri di amministrazione: un'analisi empirica sulle società quotate italiane. In Pittino D., Viganò R., Zattoni A. (Eds.), La retribuzione del top management: incentivi, carriera e governance. Milano, Egea, pp. 141-181.

Minichilli A., Zattoni A. (2017). Corporate governance - Non solo regole. Economia \& Management, 4, 45-49.

Minichilli A., Zattoni A., Zona F. (2009). Making boards effective: An empirical examination of board task performance. British Journal of Management, 20(1), 55-74. DOI: $10.1111 / \mathrm{j} .1467-8551.2008 .00591 . x$ 
Ventoruzzo M. (2005). Experiments in Comparative Corporate Law: The Recent Italian Reform and the Dubious Virtues of a Market for Rules in the Absence of Effective Regulatory Competition. European Company \& Financial Law Review, 2, 207-269. DOI: 10.1515/ecfr.2005.2.2.207

Ventoruzzo M. (2015). The Disappearing Taboo of Multiple Voting Shares: Regulatory Responses to the Migration of Chrysler-Fiat. Law Working Paper $\mathrm{N}^{\circ} 288$, ECGI.

Zattoni A. (1999). The Structure of Corporate Groups: the Italian Case. Corporate Governance: An International Review, 7(1), 38-48. DOI: 10.1111/1467-8683.00127

Zattoni A. (2003). I piani di stock option in Italia: diffusione e caratteristiche. Economia \& Management, 6, 71-90.

Zattoni A. (2007). Stock incentive plans in Europe: empirical evidence and design implications. Corporate Ownership and Control, 4(4), 56-64. DOI: $10.22495 / \operatorname{cocv} 4 \mathrm{i} 4 \mathrm{p} 5$

Zattoni A. (2009). Corporate Governance in Italy: The Structural Conflict of Interests Between Majority and Minority Shareholders. In Lopez Iturriaga F.J. (Ed.). Codes of Good Governance Around the World. New York: Nova Science Publishers.

Zattoni A. (2015). Corporate Governance. Milano, Egea.

Zattoni A., Cuomo F. (2008). Why Adopt Codes of Good Governance? A Comparison of Institutional and Efficiency Perspectives. Corporate Governance: An International Review, 16 (1), 1-15. DOI: 10.1111/j.1467-8683.2008.00661.x

Zattoni A., Cuomo F. (2010). How Independent, Competent and Incentivized Should Non-Executive Directors Be? An Empirical Examination of Good Governance Codes. British Journal of Management, 21(1), 63-79. DOI: 10.1111/j.14678551.2009.00669.x

Zattoni A., Cuomo F. (2015). Institutional Changes and Ownership Patterns in Italy. In Goranova M., Verstegen R.L. (Eds.). Shareholder empowerment, UK, Palgrave-MacMillan.

Zattoni A., Cuomo F. (2016). An Evolutionary Overview of the Ownership, Governance and Strategy of Mediobanca: From the Kingmaker of Italian Capitalism to a Large Financial Conglomerate. In Mallin C. (Ed.). Handbook on Corporate Governance in Financial Institutions. Cheltenham, Edward Elgar, pp. 7-34.

Zattoni A., Minichilli A. (2009). The diffusion of equity incentive plans in Italian listed companies: What is the trigger? Corporate Governance: An International Review, 17(2), 224-237. DOI: 10.1111/j.1467-8683.2009.00732.x

Zattoni A., Mosca C. (2012). Corporate governance and initial public offerings in Italy. In Zattoni A., Judge W. (Eds.). Corporate Governance and Initial Public Offerings: An International Perspective. Cambridge, Cambridge University Press.

Zona F., Zattoni A. (2007). Beyond the Black Box of Demography: Board Processes and Task Effectiveness within Italian Firms. Corporate Governance: An International Review, 15 (5), 852-864. DOI: 10.1111/j.1467-8683.2007.00606.x 